\title{
A PAISAGEM URBANA, ESPAÇOS LIVRES CÍVICOS ANÁLISE, CRITÉRIOS DE PROJETO E AVALIAÇÃO
}

\author{
ROGÉRIO AKAMINE
}

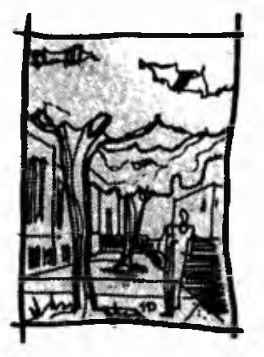

A preocupação do bem-estar do homem e sua vida na cidade foi a principal motivação para o desenvolvimento deste trabalho.

Numa época em que a distribuição da população do país é predominantemente urbana, sobre a rural, e que todo esse contingente está convivendo entre si numa aglomeração que envolve abrigos, construções e espaços livres de edificação, ocorre uma carência de organização espacial, funcional e a de atendimentos a necessidades mínimas de vida.

Os espaços livres de edificação de caráter cívico, sendo objetos a praça da Sé, o Memorial da América Latina e o vale do Anhangabaú, todos na cidade de São Paulo, foram escolhidos para uma abordagem que envolve análise, avaliação e estabelecimento de padrões que demonstram critérios de projeto.

Este artigo é uma parcela da essência de todo o trabalho de pesquisa desenvolvido por mim durante o ano de 1992, tomando-se como base os produtos apresentados na forma de dois relatórios: um intermediário e outro final para a FAPESP

O presente estudo tem por objetivo a avaliação de espaços livres de edificações, de caráter cívico e cujos projetos tiveram de um certo modo, intenção de atender aspectos funcionais, estéticos e de conforto ambiental. A compreensão das principais funções de um espaço com esse caráter se dá a partir do momento de concepção projetual.

O espaço livre é todo espaço não ocupado por volume edificado (espaço-solo, espaço-água, espaço-luz ao redor das edificações e que as pessoas têm acesso)"l.

Em se tratando de espaços livres de edificação, Miranda M. Magnoli coloca: "Na paisagem urbana, as expressões físicas (parcelamentos, escavações, plantações, construções, edificações, etc.) se manifestam sobre o solo em espaços não edificados"

Soluções adequadas de projeto de paisagismo urbano são produtos resultantes da abordagem e apreensão do objeto em questão, a partir de uma leitura do espaço, das suas possibilidades de estruturação e tendências de utilização. Em outras 
palavras, seria entender o potencial do espaço e lançar em forma de desenho de projeto, os meios para a realização do desejo de adequação do espaço livre urbano.

São os objetos de estudo escolhidos para essa avaliação: a praça da Sé, o vale do Anhangabaú e o Memorial da América Latina, que são três dos espaços públicos mais importantes da cidade de São Paulo.

Estes espaços se diferem entre si, em sua morfologia, processo histórico de formação e intenção de qualificação através de projetos, entretanto, o caráter cívico está presente em todos os três casos.

O confronto de considerações de projeto, comuns aos três espaços, tais como acesso, circulação, áreas de estar, visuais, composição de elementos, etc., nos permitem avaliar seus padrões de projeto.

Do ponto de vista simbólico, o espaço pode permitir o desenvolvimento de um senso de identidade sobre à população, no momento em que as manifestaçōes públicas, atividades programadas ou mesmo imagens que representam a cidade como um todo ("cartão postal"), são induzidas ou programadas para acontecer em espaços livres projetados com essa intenção.

\section{EVOLUÇĀO DA PAISAGEM URBANA}

$\mathrm{Na}$ cidade, em termos morfológicos, as construções são como células do grande organismo e as ruas são as que fazem a ligação com todas elas, possibilitando uma intercomunicação. Entre os espaços livres urbanos, as praças assumem caráter diferente dos destinados à circulação e acesso como possuem as ruas, assumindo dimensōes diversas que podem atender outras formas de utilização como o de estar, o de reunião e de atividades comunitárias, etc.

Em momentos diferentes da história, variando com o desenvolvimento econômico e social, os espaços livres podem assumir características cada vez melhores qualitativamente, dependendo da elaboração do projeto urbano, bem como de sua execução. $\mathrm{O}$ avanço econômico de uma cidade favorece uma maior concentração de população urbana, mais construções e maior exigência de qualidade do espaço público.

A cidade de São Paulo, centro de uma série de projetos urbanos importantes, tem sua evolução histórica caracterizada por um movimento econômico crescente de enriquecimento, principalmente durante e após o auge da economia do café na primeira metade do séc. XX.

Junto com esse fenômeno, há um aumento de população e de suas necessidades, tornando-se imprescindível a organização dos espaços para atender funcionalmente seus habitantes. 
Os projetos urbanos são superados com o passar do tempo, exigindo destes uma escala de atendimento cada vez maior, para uma população crescente. $O$ centro de São Paulo, por exemplo, foi modificado por muitas vezes, como mostra Benedito Lima de Toledo em seu livro São Paulo: Três Cidades em um Século ${ }^{2}$.

Para o entendimento das soluções de projeto para espaços urbanos, devemos compreender a evolução da morfologia ao longo do tempo e resgatar todas as exigências existentes, soluções adotadas em cada período e reformulações decorrentes de novas demandas e necessidades da cidade.

Os textos e imagens que seguem têm a intenção de dar uma visão comparativa dos três objetos de estudo, em períodos mais significativos em termos de transformações morfológicas ao longo do tempo. Em seguida, considerações de cada elemento constituinte do projeto, a nível de soluções adotadas para uma análise comparativa entre os três objetos.

\section{PRAÇA DA SÉ}

1881

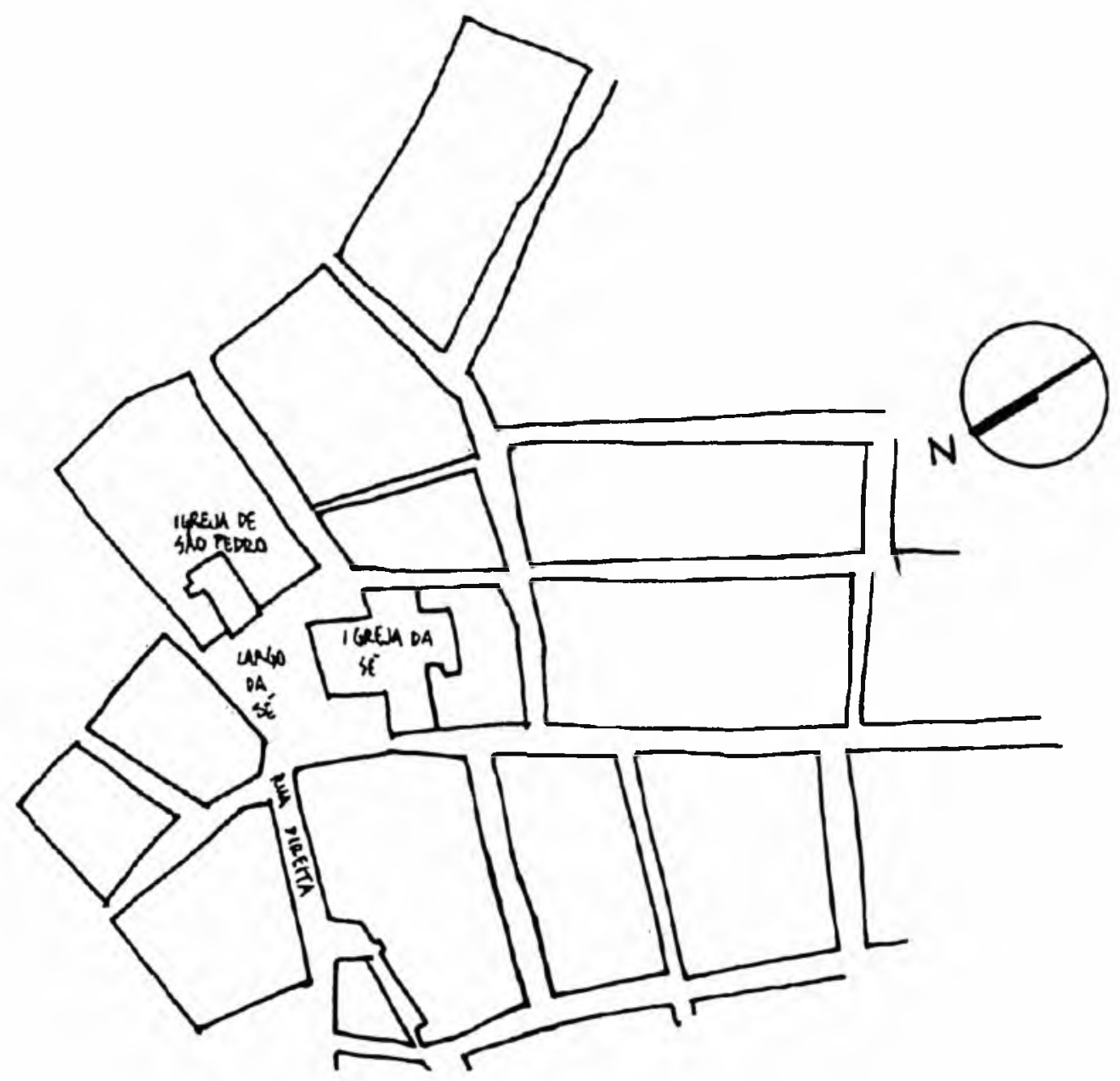




\section{1}

Origem: largo da Igreja da Sé. O largo da Sé foi formado na primeira ocupação da cidade de São Paulo, numa convergência de ruas, cujo espaço alargado possibilitaria atividades ligadas à igreja, tais como festas, cortejos, reuniões de fiéis.

Característica morfológica: Estrutura espacial definida pela frontalidade da igreja da Sé e a de São Pedro, também pelos edifícios próximos aos templos, os quais se agrupavam em quarteirões irregulares em sua forma.

A configuração espacial do largo é definida além da estrutura edificada como também pelas atividades comunitárias que exigem um espaço mais amplo onde seja possível a sua realizaçāo.

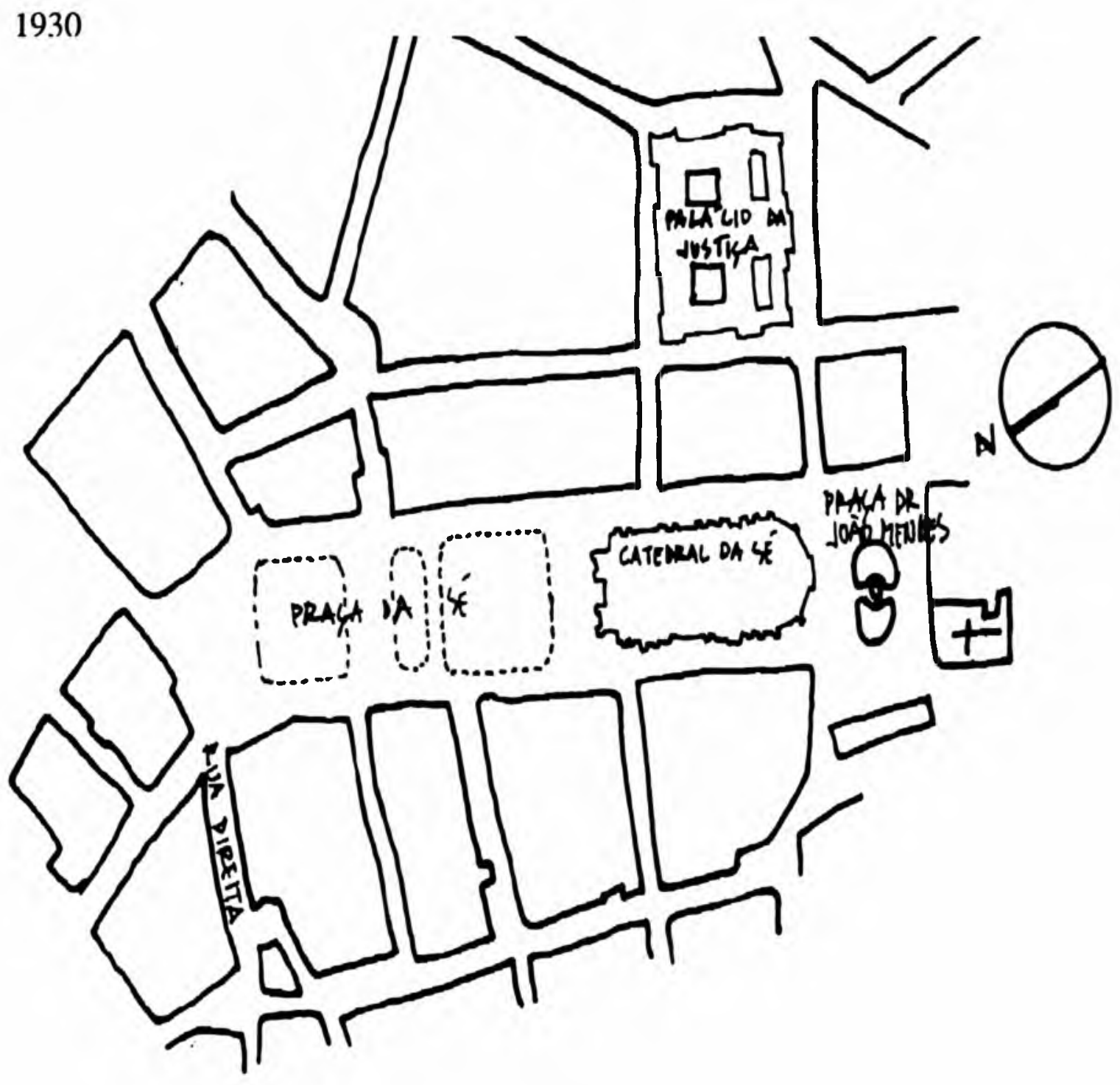


Na segunda década do séc. XX, inicia-se a ampliação do largo da Sé passando a ser praça. Para a abertura desse novo espaço, dezenas de construções são demolidas, inclusive as igrejas da Sé e de São Pedro.

Em lugar desse terreno de tecido urbano removido, havia a intenção de se construir a catedral da Sé de caráter metropolitano e uma grande praça. Todo esse processo de renovação do centro da cidade vem simbolicamente demostrar o crescimento econômico e populacional da cidade.

A implantação da catedral definiu uma nova praça da Sé, voltando a porta principal para a mesma direção que a igreja demolida, e com seus fundos a praça Dr. João Mendes, que ficou num plano secundário de importância tanto simbólica como espacialmente, graças ao posicionamento do edifício que tem frente $\mathrm{e}$ fundos bem definidos.

1954

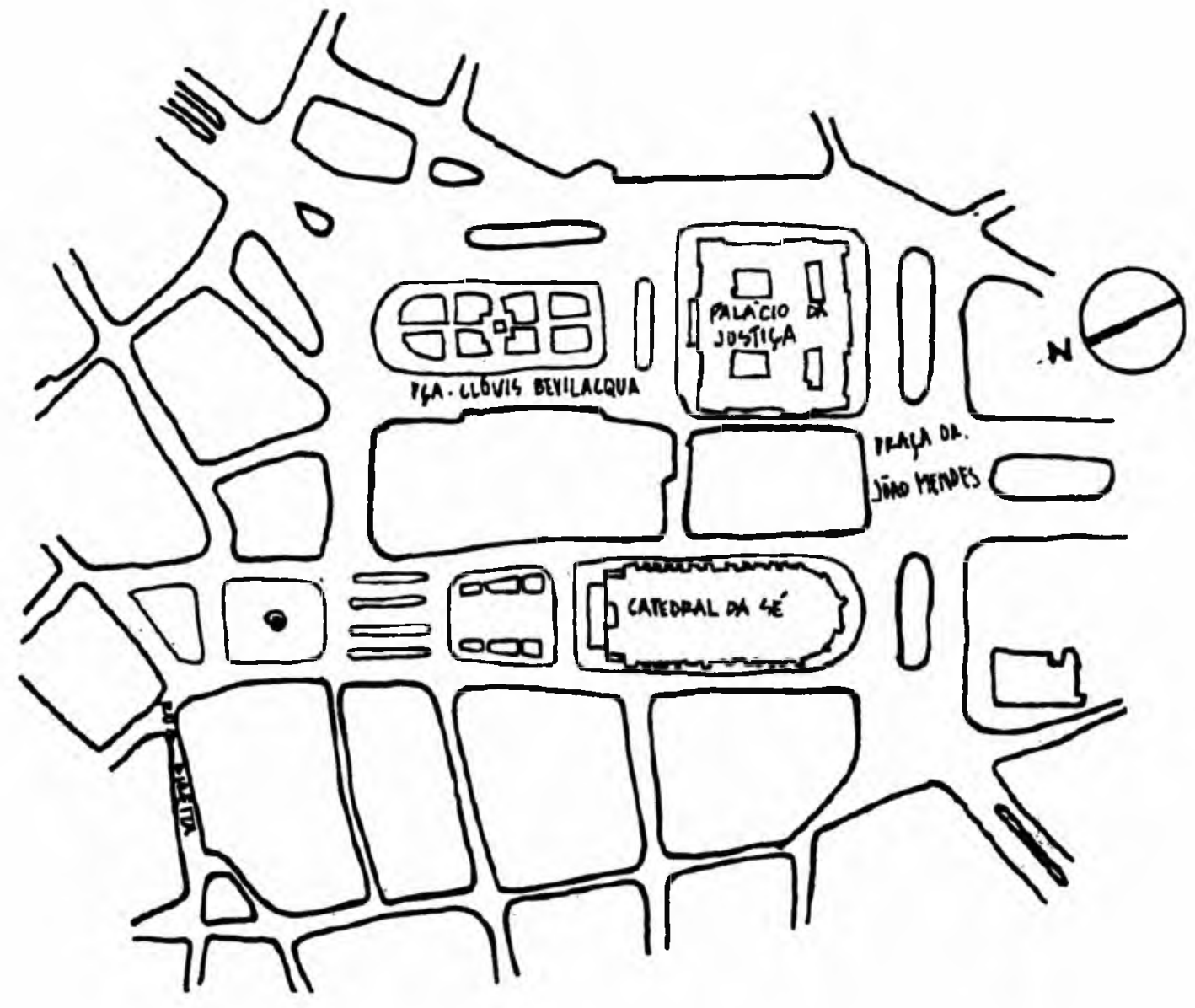




\section{4}

Na gestão do prefeito Prestes Maia, na década de 30, foi aberta, através de demolições de quarteirões, a praça Clóvis Bevilacqua.

Essa praça vinha dar uma abertura maior de espaço para que o edifício do Palácio da Justiça pudesse estruturá-la. Houve uma nova contextualização daquele edifício para a cidade.

Da mesma forma que a praça da Sé (a partir da ampliação de 1952), a praça Clóvis recebeu por um bom período pontos de parada de ônibus.

Estas duas praças eram separadas e cada uma delas tinha sua própria identidade. Uma com a presença do Palácio de Justiça e do terminal de ônibus, outra com a catedral e a praça de estar e eventos que faz parte do contexto da catedral.

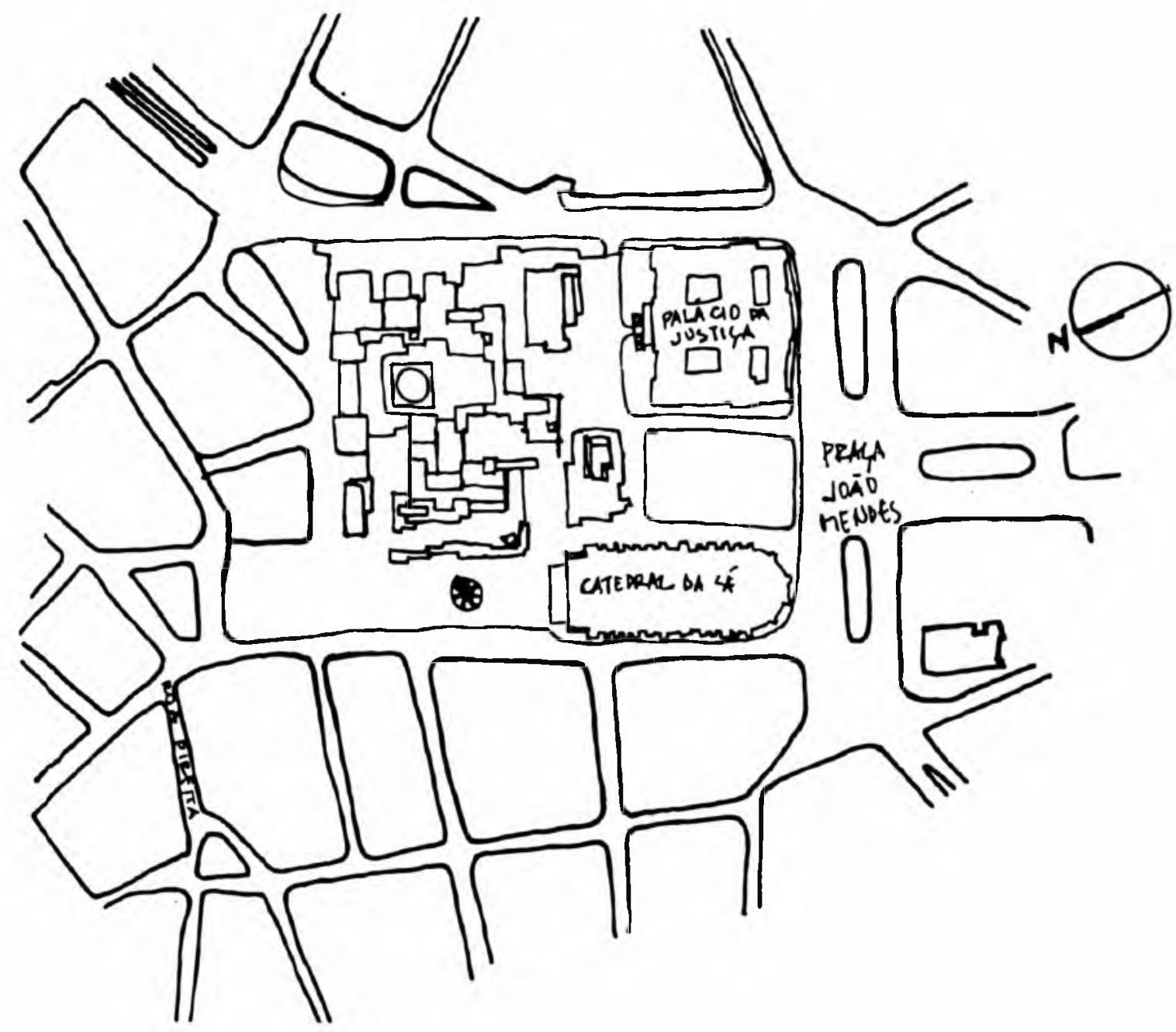


Tem como estrutura geral um espaço muito fragmentado e de pouca clareza espacial.

As edificações adjacentes já não são suficientes para emoldurar ou dar suporte à estrutura espacial da nova praça. $O$ usuário já não consegue apreender o espaço livre como um todo, pela indefinição morfológica do conjunto.

Com a ampliação do espaço da Sé, adotou-se uma solução de desenho com uma fragmentação exagerada de formas geométricas, inúmeros patamares e jardineiras.

Essa proposta não estabelece clareza de estrutura da praça, pois não é fácil a compreensão de sua estrutura e somado ao grande número de elementos como mobiliário e esculturas, torna-se difícil a leitura mais nítida daquele espaço pelo usuário.

O quarteirão que dividia as praças Clóvis Bevilacqua e Sé é demolido em função da instalação da estação Sé do metrô.

Tendo como elementos determinantes, funcionalmente, as saídas do metrô e os fossos de iluminação e ventilação, a Prefeitura Municipal de São Paulo propôs e executou o projeto da atual praça da Sé.

\section{VALE DO ANHANGABAÚ}

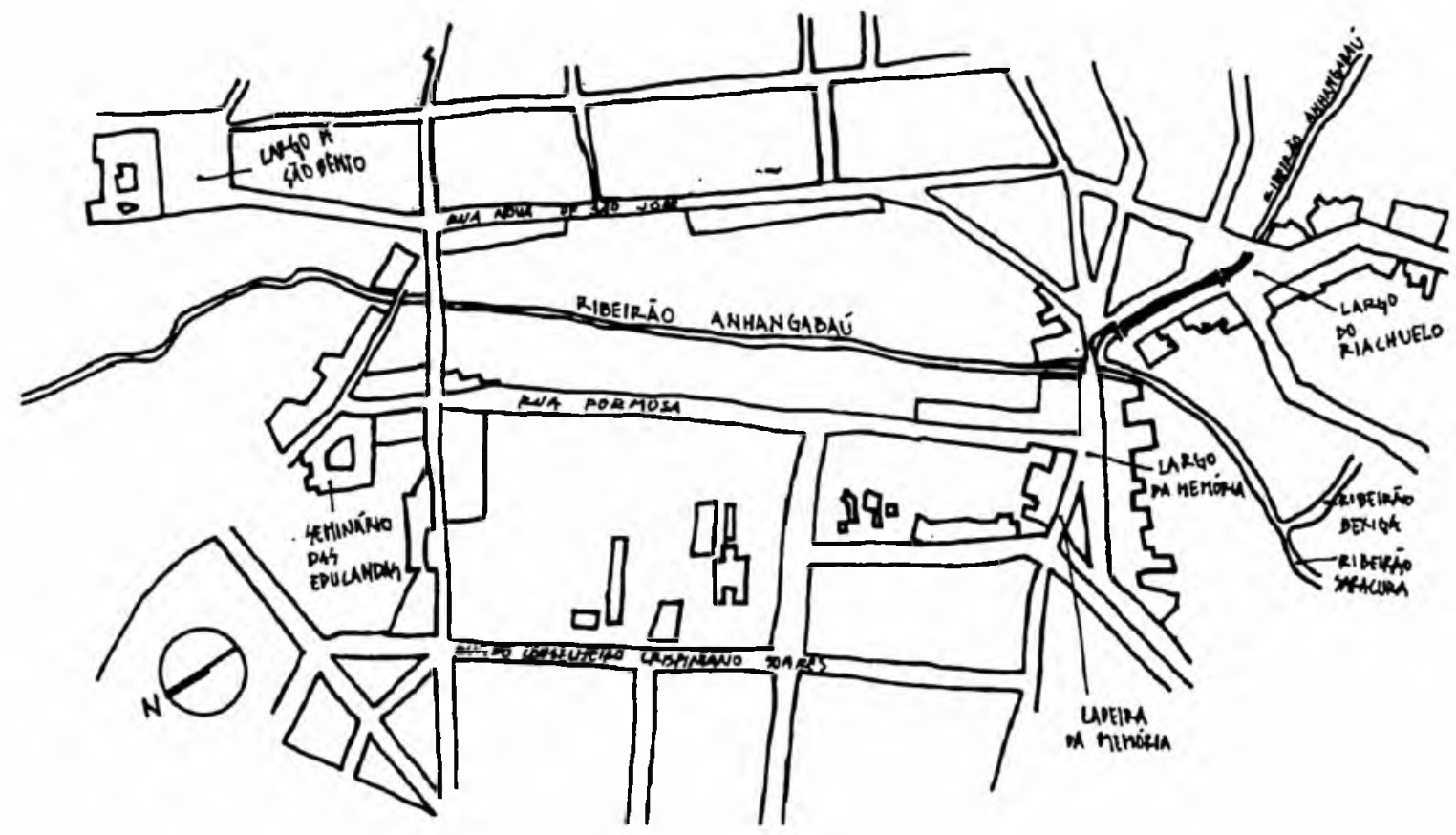




\section{1}

Origem: Avanço do tecido urbano do centro velho da cidade de São Paulo em direção oeste vencendo a várzea do Anhangabaú. Esse "vencer" o vale significa que a transposição do mesmo pode ser efetivada através dos viadutos de Santa Efigênia e do Chá.

Característica morfológica: Estrutura espacial linear que se estrutura sobre a área de várzea do ribeirão Anhangabaú para onde davam os fundos de quintal e chácaras.

A dimensão da largura-vale é definida pelas margens do ribeirão Anhangabaú até onde se tem terra firme não inundável para a fixação de construções. Sem uso específico, essa área poderia atender aos despejos residuais das casas vizinhas. $O$ vale era um verdadeiro fundo de quintal.

1930

A situação do vale do Anhangabaú em 1930, era bem diferente das primeiras ocupações. O projeto urbanístico do arquiteto francês Bouvard, datado de 1922, apropriava as áreas de várzea com um parque, o parque Anhangabaú.

O ribeirão Anhangabaú foi canalizado eliminando-se assim uma barreira que separava as duas partes da cidade, saneando de vez a área.

Era possível atravessar o parque de uma parte para outra da cidade, no entanto, a passagem mais direta e prática era através das estruturas metálicas dos viadutos do Chá e de Santa Efigênia que ligavam duas colinas.

1930

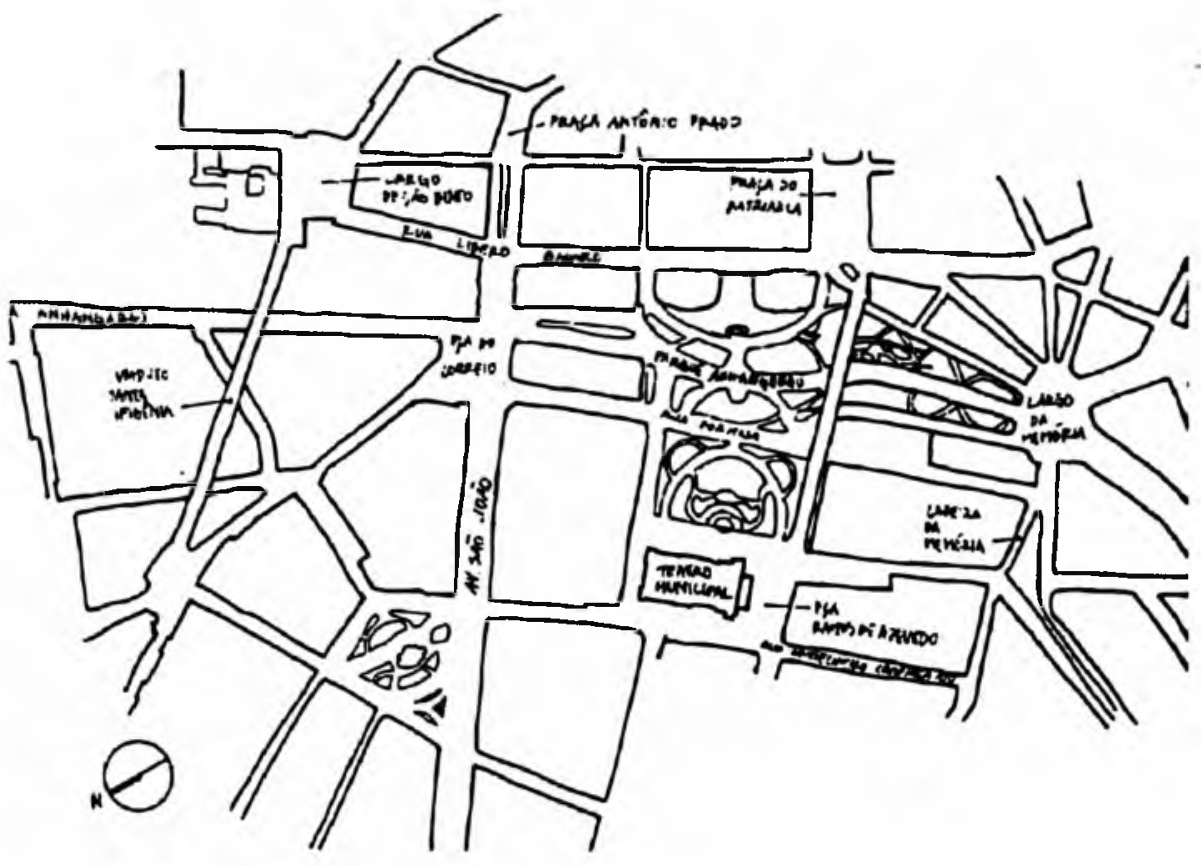


A área em questão continuou livre de edificações, mantendo a leitura do vale, apesar da não visualização do ribeirão Anhangabaú. $O$ aspecto de parque era dado pelos canteiros de plantas num desenho romântico francês. Era quase uma via-parque. Esse projeto trouxe um caráter mais urbano para o terreno que era até uma simples várzea. $O$ lazer e o embelezamento da cidade foram as principais intenções dessa intervenção espacial.

Os dois palacetes Prates, que estavam localizados na rua Líbero Badaró, possuíam terraços voltados para o parque Anhangabaú, no primeiro plano e em segundo o Teatro Municipal e o Hotel Esplanada. Os visuais e eixos marcantes na paisagem se dava na direção transversal a maior dimensão do vale.

\section{4}

Nas décadas de 20 e 30 , com a difusão do automóvel, o grande ideal de cidade era aquele que permitisse uma boa adequação para utilização desses veículos.

Uma das características do Plano de Avenidas de Prestes Maia (nos anos 30) era a implantação de autovias em fundos de vale.

Nessa forma de projetar uma importante ligação entre o norte e o sul da cidade se daria perfeitamente seguindo o leito do ribeirão Anhangabaú.

1954

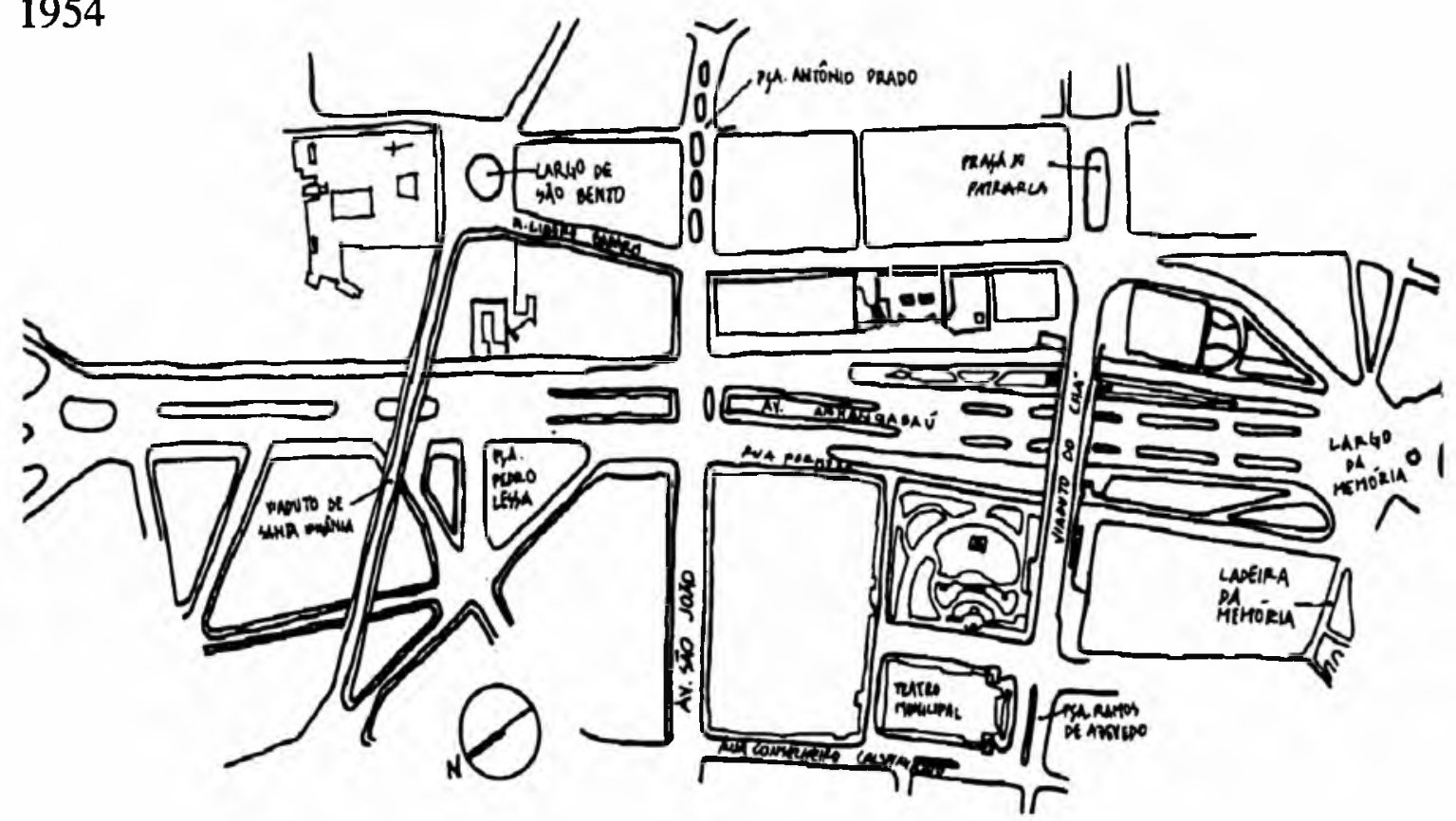

O parque do Anhangabaú foi cortado pela importante ligação viária, a avenida Anhangabaú. Do projeto de Bouvard restou a porção próxima ao Teatro Municipal, pois ficava fora da área ocupada pelas novas vias. 
Reintroduz-se nesse local a barreira longitudinal, que anteriormente se dava pelo ribeirão e dessa vez pela avenida e seu crescente fluxo de veículos.

A estrutura linear do espaço enfatiza-se pela leitura da baixada do vale entre duas colinas. A travessia entre essas se torna mais intensificada nos viadutos.

O vale passa a ser concentração de pontos de ônibus e a galeria Prestes Maia o acesso para os mesmos.

1992

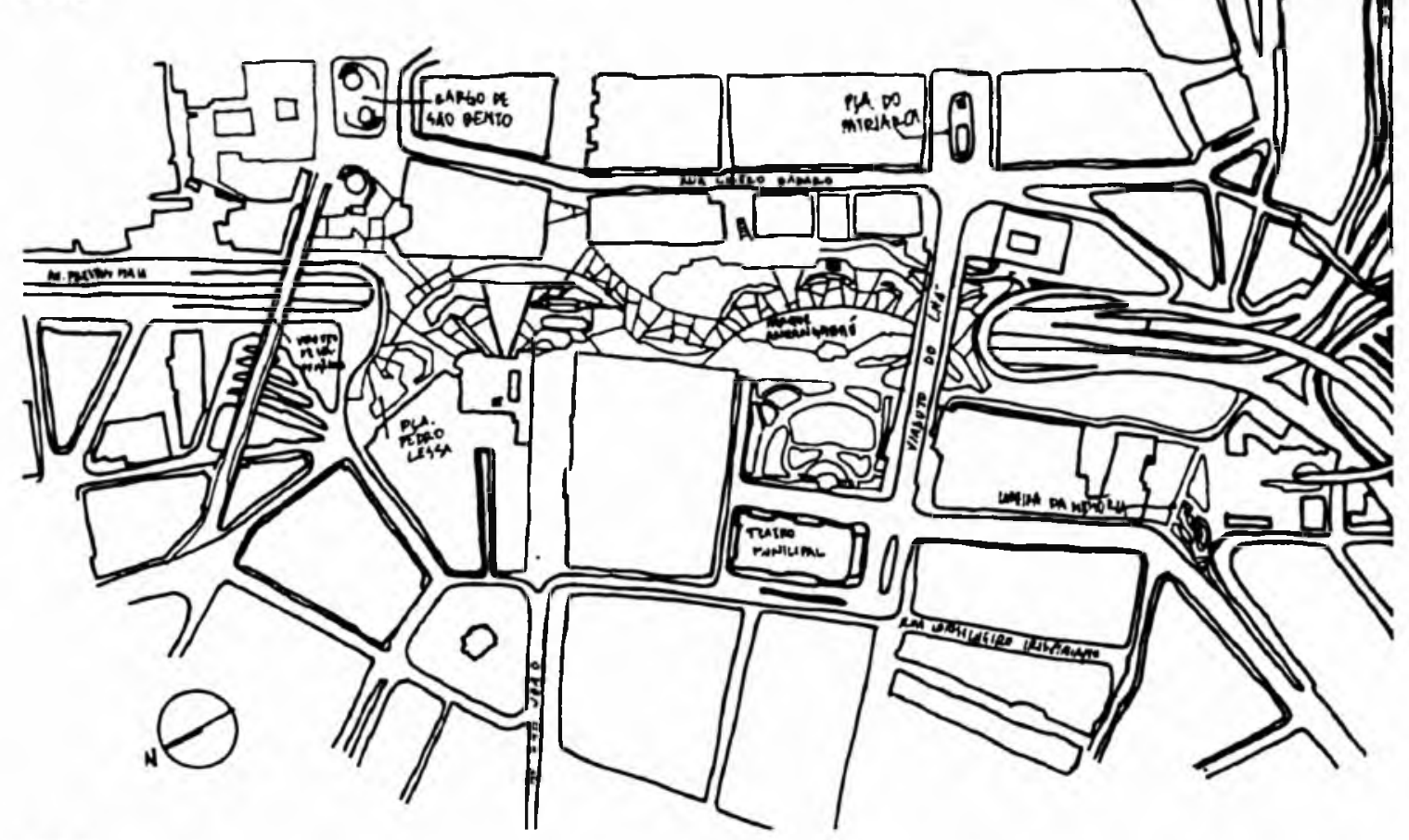

1992

Em 1981, na gestão do prefeito Reynaldo de Barros, houve um concurso para projeto do vale que pedia soluções para problemas de compatibilização de funções, melhoria estética e combate a degradação do centro.

O novo projeto para o vale do Anhangabaú traz como objetivo principal devolver o vale aos pedestres. A solução foi a separação de veículos e pedestres em níveis diferentes. A equipe vencedora era formada pelos arquitetos Jamil Kfouri, Rosa Kliass e Jorge Wilheim. Esse espaço tem forte potencial de caráter cívico, pois trata-se de um grande piso construído e alguns canteiros.

Vários são os acessos e percursos, e os pedestres podem ir da cidade velha para a nova através do Anhangabaú, no entanto, o aspecto de baixada de vale continua presente. 
Os edifícios adjacentes são estruturadores da espacialidade de forma linear, reforçam esse aspecto, pois dão a sensação de contenção do espaço para quem está no vale, esses são altos e dispostos na direção da maior dimensão.

O contexto urbano em que esse espaço se encontrava, na época do concurso e das discussões em torno desse tema, não era mais aquele que possuía os palacetes de Prates e edifícios baixos, mas sim altas torres que reforçavam o caráter linear do vale. Houve uma mudança morfológica em relação à proporção entre as alturas dos edifícios e o espaço livre entre eles.

\section{MEMORIAL DA AMÉRICA LATINA}

1887

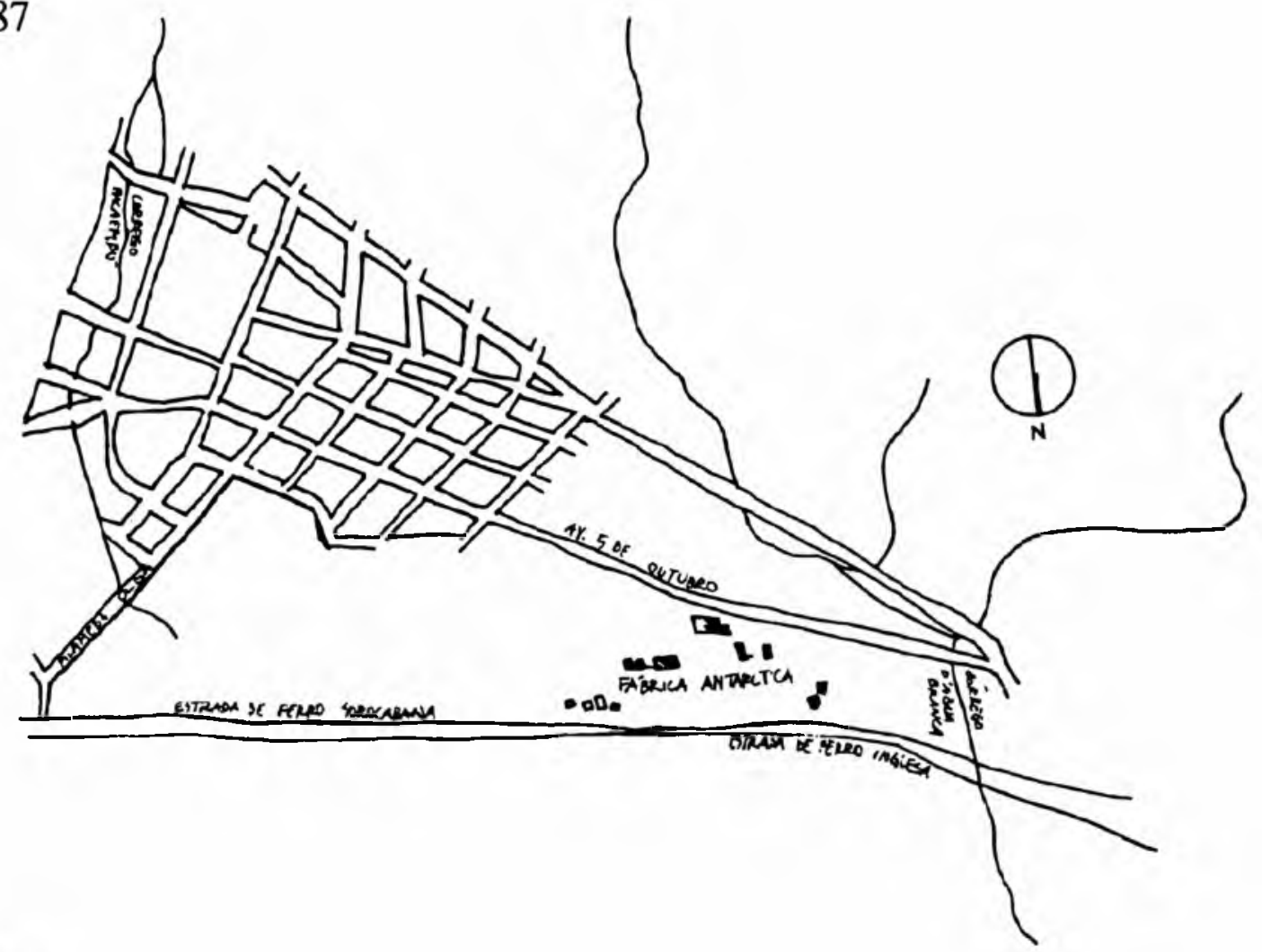

1887

Origem: No final do séc. XIX e início do XX, o local onde se localiza o Memorial da América Latina era uma área de várzea do rio Tietê. $O$ rio corria em meandros e em épocas de cheia tal várzea era inundada. $\mathrm{O}$ bairro da Barra Funda teve como marco inicial de surgimento a chácara Carvalho, do Conselheiro Antônio da Silva Prado.

Característica morfológica: Área plana de várzea, inundável na época de cheias, que dificultava a expansão da cidade para além-rio. 
O rio e suas margens inundáveis eram as principais barreiras para a zona norte da cidade.

1930

As chácaras que se localizavam desde o bairro de Campos Elíseos ao da Água Branca começam a se transformar no séc. XX e em 1930 o caráter passou a ser estritamente residencial.

No caso da Barra Funda as estradas de ferro Sorocabana e a Santos-Jundiaí passavam pela área, estando na direção paralela ao rio Tietê. Estas linhas férreas implantadas por volta de 1875 , tinham a função de ligação direta entre a produção da lavoura de café e seu escoamento por estrada de ferro até o porto de Santos, principal porta para o mercado externo do estado de São Paulo.

1930

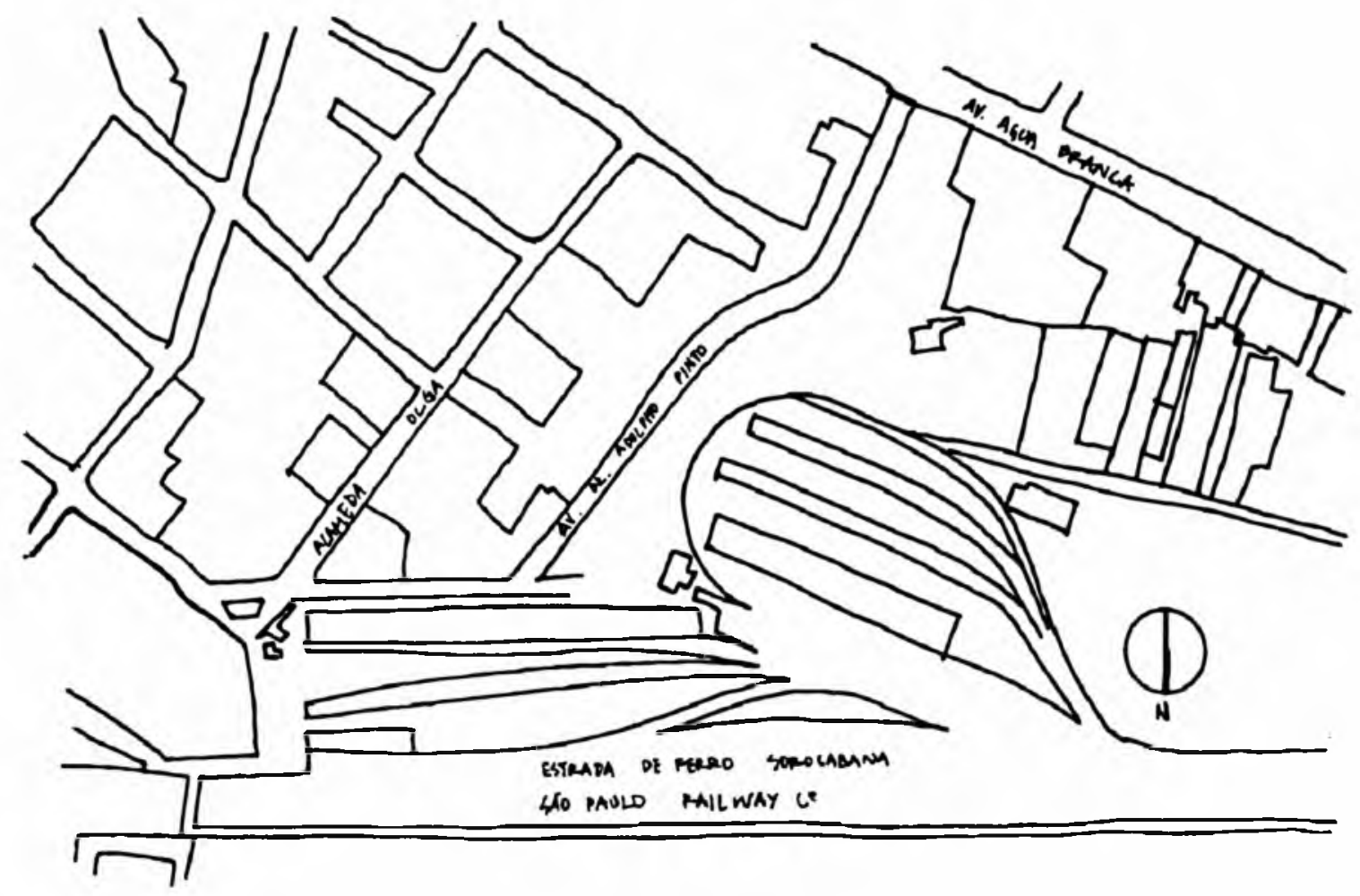

Assim como os bairros de Santa Efigênia, Brás, Consolação, Moóca, Pari, Ipiranga e Água Branca, o bairro da Barra Funda surgiu em função do progresso ferroviário, provocando o loteamento das chácaras que circundavam o centro da cidade. A caracterização morfológica do bairro gira em torno desse processo econômico, ou seja, para apoio a essas linhas de trem, surgiram galpões e pela facilidade de transporte se instalavam indústrias e por conseguinte a população ligada a essas atividades. 
Depois passa a ser constituído de casarões, cujos donos eram os produtores e homens que se enriqueceram com o café, com a crise de 1929, o bairro da Barra Funda se transforma outra vez.

Os grandes casarões são sublocados e surgem muitos cortiços. Galpões de armazém e industriais diminuem o ritmo de trabalho na medida em que se dava a crise do café. No trabalho fotográfico de Dulce Soares ${ }^{5}$ um histórico relata tais caracterizações.

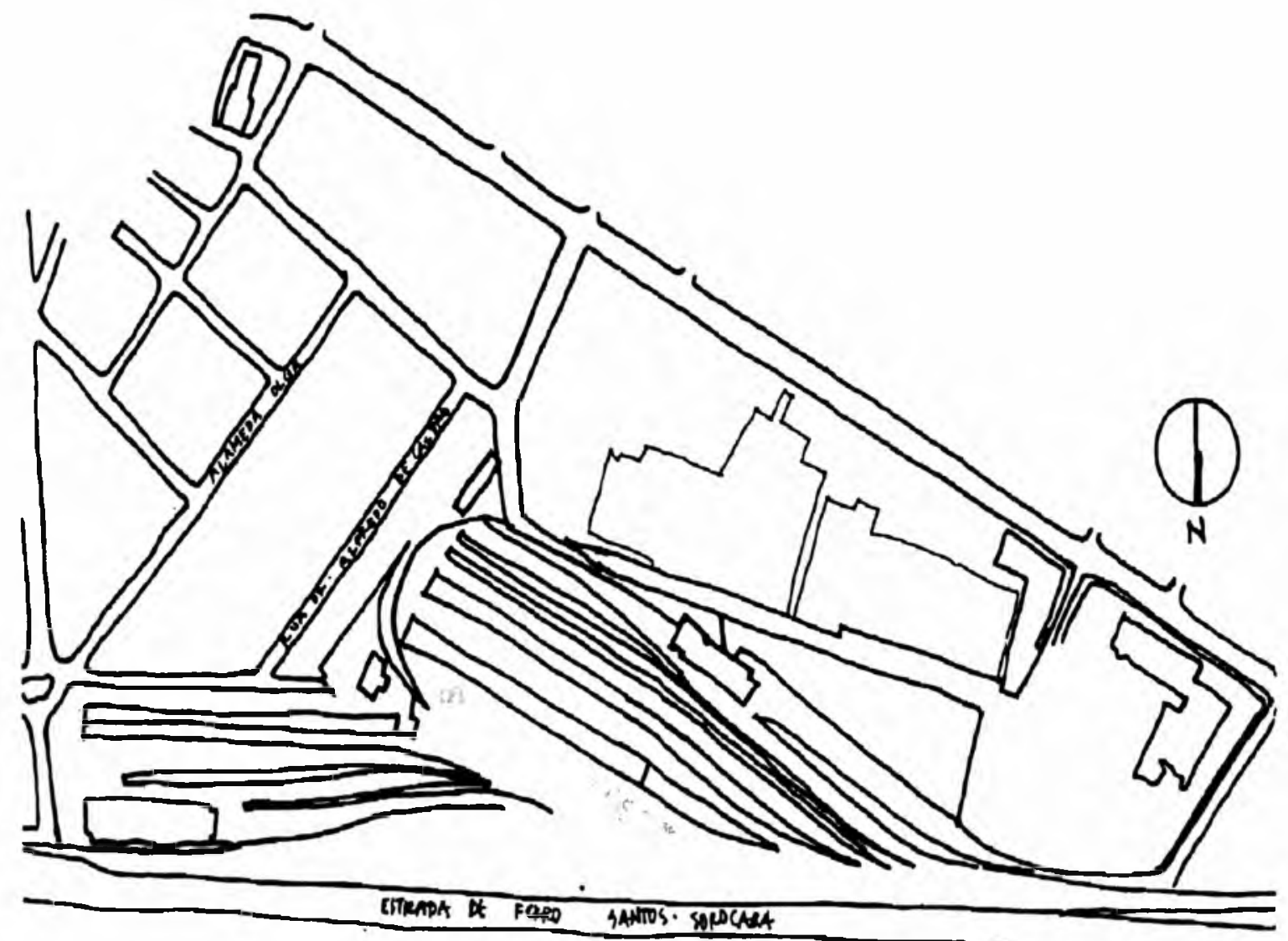

O espaço era no bairro Barra Funda, que se caracterizava pela indústria remanescente, junto a linhas de trens, galpões de armazéns e a estação Barra Funda do metrô; era o projeto do Memorial da América Latina. 


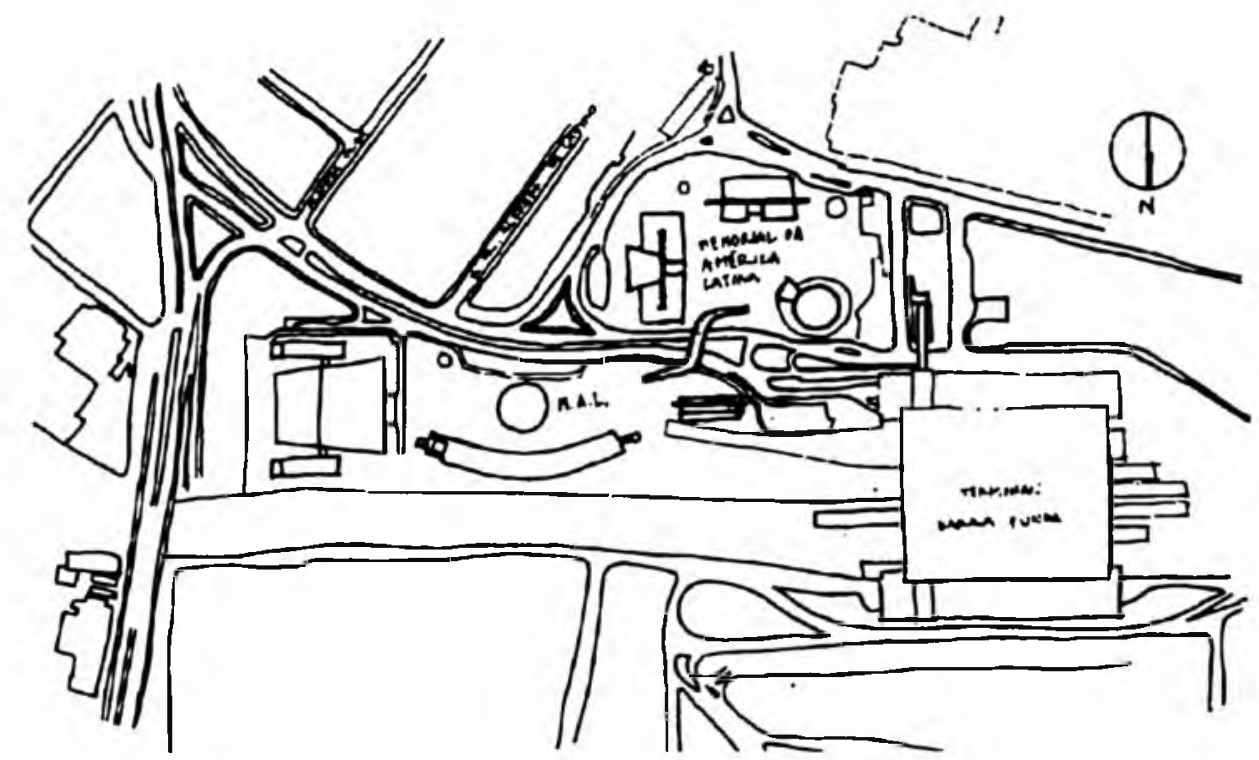

1992

No final da década de 80 , o governo do estado de São Paulo decidiu implementar a idéia de se criar um espaço na capital, que reunisse a cultura e relacionamento entre países da América Latina.

Foi convidado para propor tal projeto o arquiteto Oscar Niemeyer. Seguindo a linguagem de sua produção arquitetônica de Belo Horizonte, Rio de Janeiro e Brasília, Niemeyer compôs formas curvas e com leveza formal para os edifícios do Memorial. A implantação destes edifícios seguiu uma lógica interna de composição. Restaurante, Biblioteca e Salão de Atos numa parte, e na outra, ligada à primeira por uma passarela sobre a via, Administração, Pavilhão da Criatividade, Auditório e o recente Parlamento das Américas.

Essa visão de composição levou ao encaminhamento de um projeto com nenhuma integração com o entorno, sem acessos nas várias extremidades, o espaço do Memorial é uma ilha urbana. Dentro dessa ilha a percepção espacial é esvaziada pela amplitude do espaço exagerada e a falta de definição dos espaços livres através da disposição dos edifícios.

\section{ASPECTOS DA PAISAGEM}

Os aspectos de paisagem devem ser observados na concepção do projeto urbano, quando há a preocupação em se considerar os espaços livres de edificação e seus eixos, visuais, pontos focais, percursos, acessos, etc., a solução da proposta pode acrescentar qualidade de integração com o contexto existente. Muitas vezes, é necessário propor uma nova idéia sobre a já existente, implantada de alguma forma. Nesse momento uma análise de recuperação da primeira idéia pode 
trazer aspectos ainda existentes que vão interferir no novo projeto, bem como idéias e soluções que mais se adaptem a época.

\section{Praça da Sé}

A praça da Sé exprimia intenções claras quando da construção da catedral metropolitana e sua praça frontal. Aquele espaço possuía proporções generosas em relação ao tecido urbano do entorno já existente. A grande catedral de dimensão significativa (capacidade aproximada de 1.000 fiéis) era uma grande referência e a praça dava condições de se visualizar à distância. $O$ piso da praça bem definido, com as filas de palmeiras reais em suas laterais, ao mesmo tempo que reforçava a idéia de praça de atividades cívicas, leva a focalização à catedral.

Com a união com a praça Clóvis Bevilacqua, a praça da Sé antiga perdeu sua definição espacial de uma das laterais. Outro eixo era proposto, que ligava a parte mais baixa à mais alta da praça Clóvis, porém não tem o caráter tão forte pela ausência de elementos verticais ou mesmo fechamentos que reforcem a idéia de eixo.

Os principais percursos ocorrem na direção norte-sul da praça nos dois eixos (praça Clóvis e Sé antiga), no eixo rua Direita - acesso metrô e parque Dom Pedro II.

Entrando pela rua Direita, podemos fazer a trajetória na direção da catedral passando pelo piso definido, pelas palmeiras imperiais e marco zero, terminando na praça João Mendes, atrás da catedral.

Da praça João Mendes, acessando pela lateral do Palácio da Justiça nos deparamos com os blocos escalonados com águas e vegetação se desenvolvendo a medida que o terreno inclina e que se desce as escadas em direção ao parque Dom Pedro II.

Uma fileira de palmeiras marca desse ponto o caminho que leva ao acesso principal da estação Sé, parte na direção da rua Barão de Paranapiacaba.

\section{Vale do Anhangabaú}

O projeto do arquiteto Bouvard estabelecia com seu desenho francês, simétrico, um eixo cuja direção era marcada pelos terraços dos palacetes Prates para o Teatro Municipal na cidade nova. O visual continha planos: dos jardins e caminhos, das renques de palmeiras, escadarias e fonte, depois o teatro e o Hotel Esplanada.

O parque Anhangabaú possuía ruas passando em seu interior, numa época em que os automóveis eram em pequeno número: era uma via-parque. 
As pessoas que precisavam ir da cidade velha à nova usavam os viadutos do Chá e de Santa Efigênia. Só desciam ao parque as pessoas que iam realmente usar aquele espaço para passeios e estar.

No atual projeto, os autores quiseram manter clara a idéia de vale, não colocando elementos que bloqueassem essa intenção.

Todo o desenho do espaço e equipamentos foram pensados para não interferir em momentos de grande concentração de pessoas e nos dias normais, dar uma certa estruturação ao espaço. A idéia de versatilidade desse projeto, o que vem demostrando bons resultados, com ressalva aos canteiros próximos ao viaduto do Chá em dias de grandes eventos.

eixo da avenida São João também foi considerado, pois liga visualmente a torres do Banco do Estado de São Paulo ao pịco do Jaraguá (hoje não tão nítido nas proximidades do centro). A colocação do portal do Boulevard São João, bem como as colunatas em frente à escola de música não integravam o projeto original. É de autoria da Empresa Municipal de Urbanização.

Os percursos e caminhos seguiram a demanda de fluxos que é na maior dimensão, ligando as duas estações de metrô. $O$ desenho de arcos que fazem evoluções ao longo deste percurso é resultado do rebatimento do arco remanescente do desenho de Bouvard.

O mirante do Boulevard São João veio do partido de busca de soluções para diferenças de níveis, resultantes da configuração dos túneis subterrâneos. Desta forma a parede de água foi incorporada num conjunto de fontes ambientalizando o café que fica sob o mirante. Emoldurando o edifício do Correio, estão várias fontes e um piso em forma de caminho traçado por raios cujo centro está na porta principal do edifício. Essa intenção pode ser entendida vista do alto.

A marcação da localização do palco próximo à renque de palmeiras, que deixava o viaduto do Chá como camarote lateral nunca foi respeitada, pois os organizadores dos eventos preferem ter o viaduto do Chá como fundo do palco e todo o piso do vale para o público, o que atende a um maior número de pessoas.

\section{Memorial da América Latina}

Pelo acesso principal, passagem subterrânea à rua, ao subir as escadas, temos o grande piso de concreto e os edifícios de Niemeyer na altura da visão. A escultura vermelha já chama atenção, pois está no eixo visual do usuário que adentra aquele espaço e contrasta muito pelo fundo cinza e branco e a forma geometrizada. 
A idéia era que a outra extremidade do eixo de entrada fosse marcada pelo edifício do Salão de Atos, no entanto, o espaço pouco definido pelas suas grandes dimensões, não deixa essa intenção muito clara.

O usuário é levado a seguir o percurso da primeira praça à segunda, do Pavilhão da Criatividade pela passarela. Na segunda praça, o percurso deveria seguir ao longo do Pavilhão da Criatividade; chegando ao Auditório.

Todos os edifícios possuem a forma plástica de Niemeyer, curvas cascas esbeltas de concreto, grandes vãos e.panos de vidro, o que dá uma coerência formal internamente as fronteiras com a cidade.

A passarela é ao mesmo tempo uma referência naquele espaço, como também um mirante para a cidade.

O entorno fica sem diálogo com esse projeto. Não há relação visível nem de concordância, nem de contraste com edifícios marcantes tais como os galpões industriais, o edifício de seis andares da indústria gráfica ou mesmo a estação Barra Funda. Permanece uma indiferença desse projeto com a cidade.

O Memorial da América Latina possui edificações que se apresentam como volumes únicos, colocados no espaço sem a sugestão de formação de planos ou estruturação de espaços livres.

A intenção deste projeto trata cada um dos edifícios como peça escultórica, marca característica do arquiteto Oscar Niemeyer, que já concebeu boas composições em Brasília e Belo Horizonte. Nessas localidades, a conformação espacial possibilitava uma boa relação escalar e de relação objeto e fundo. No caso do Memorial, o entorno composto por elementos heterogêneos tais como galpões baixos e compridos, edifício com seis pavimentos e a estação Barra Funda que é um volume de grandes dimensões, a composição dos edifícios deste espaço seguiu uma lógica interna que não se relaciona de forma alguma com qualquer elemento externo.

\section{RELAÇĀO ESCALAR DE FECHAMENTO DO ESPAÇO LIVRE}

Baseando-se na percepção visual humana, onde se tem aproximadamente 60 graus de abertura angular de visão e que destes $2 / 3$ estão acima da linha do horizonte, e ainda, nos 27 graus acima da linha do horizonte, podemos abarcar um edifício cuja altura é igual a distância entre o objeto e o observador, podemos relacionar tal distância a altura do objeto.

Adotando teorias de textos de Ashihara ${ }^{3}$ e do grupo do Great Londo Council ${ }^{4}$, podemos analisar o grau de fechamento dos espaços livres configurados por edificaçðes. 
Essas teorias dizem respeito à segurança em termos de orientação e domínio do campo visual que o usuário sente ao adentrar em diferentes espaços. Se D (distância entre o observador e o objeto) e $\mathrm{H}$ (altura do objeto) tiverem uma relação $\mathrm{D} / \mathrm{H}>1 / 1$ (por exemplo $3 / 1$ ) ele já passa a perder domínio do espaço e se $\mathrm{D} / \mathrm{H}<1 / 1$ (por exemplo 1/3) o observador começa a sentir sensação de enclausuramento.

Ashihara indica que as relações mais usuais entre os espaços livres são $\mathrm{D} / \mathrm{H}=$ $1 / 1,2 / 1$ e $3 / 1$, que se $\mathrm{D} / \mathrm{H}=4 / 1$, a percepção do espaço fica cada vez mais difícil, enquanto que $\mathrm{D} / \mathrm{H}=1 / 2$ a sensação é a de aprisionamento entre os edifícios.

\section{PRAÇA DA SÉ}

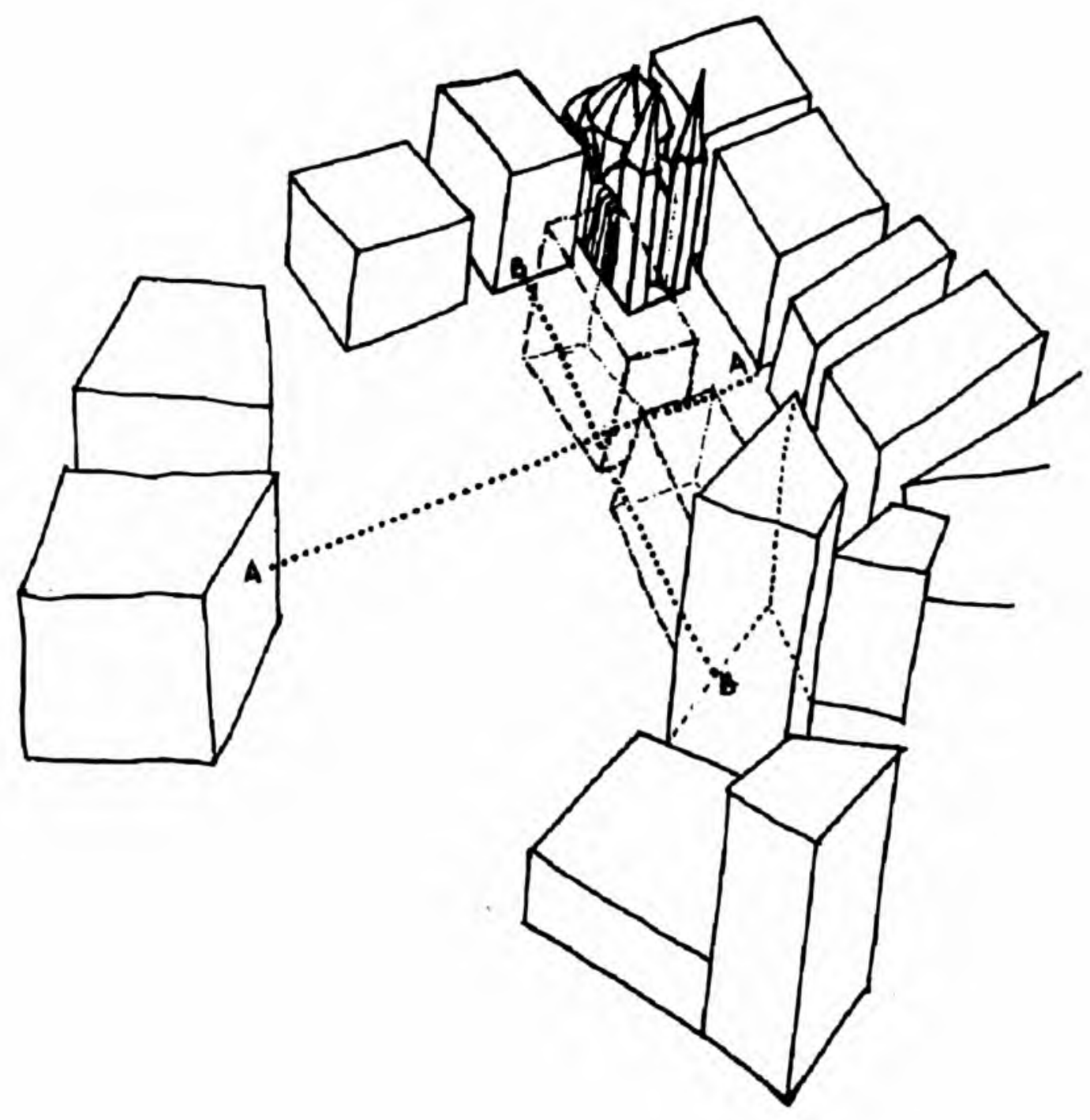




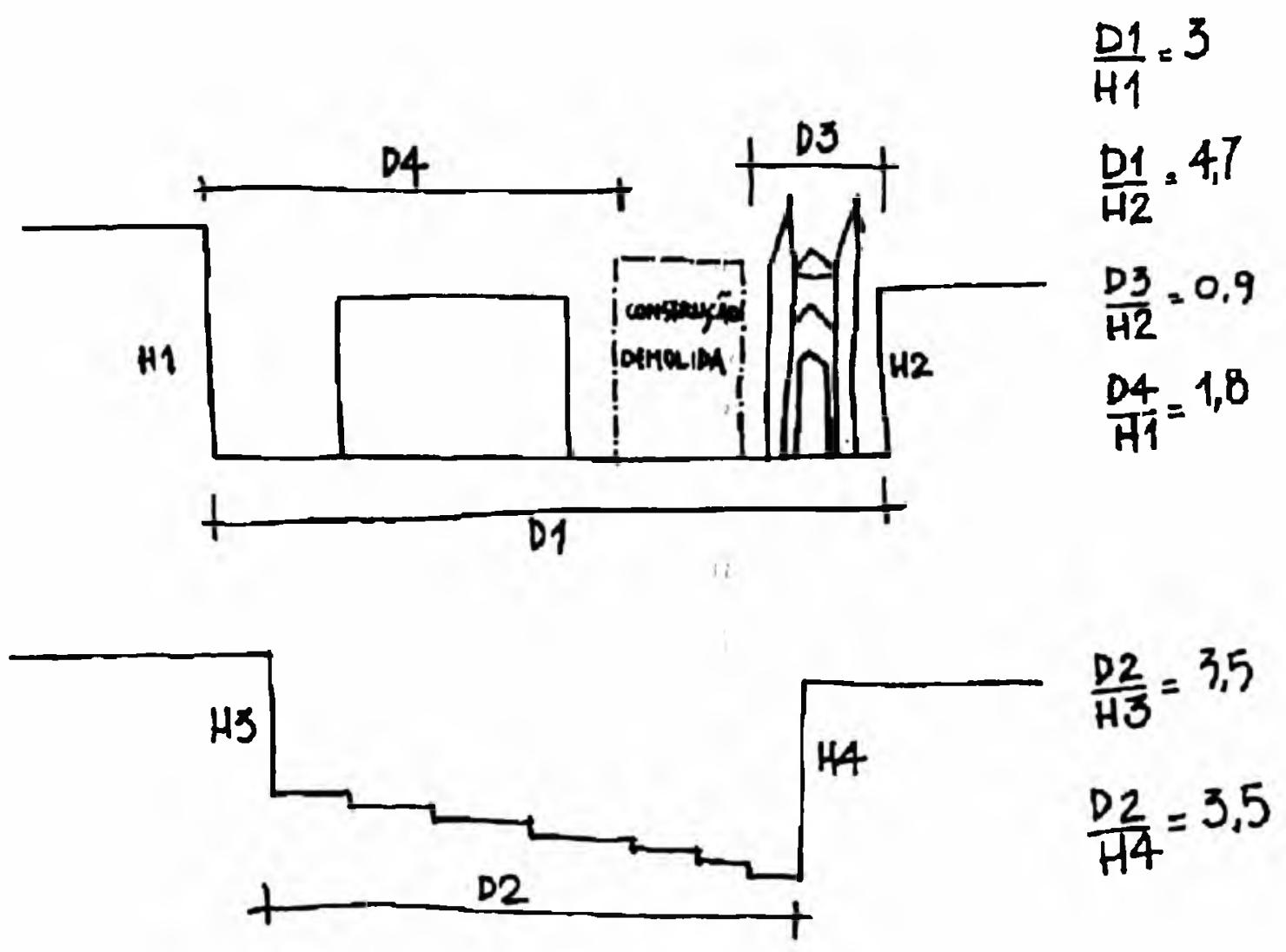

A praça da Sé apresenta um aspecto de indefinição espacial, segundo a conceituação de domínio do campo visual apresentado anteriormente.

Com a fusão das duas praças, os edifícios do entorno não possuíam dimensões que pudessem manter a relação $\mathrm{D} / \mathrm{H}$ próximo de $1 / 1$, o que fez perder a definição do espaço. A descontinuidade do conjunto de edifícios na direção do parque Dom Pedro II, bem como sua inclinação em direção à várzea do Tamanduateí favoreceram ainda mais para a perda do fechamento do espaço e equilíbrio escalar.

Verificando as relações $\mathrm{D} / \mathrm{H}$ constatamos os seguintes valores: $\mathrm{D} / \mathrm{H}=3 / 1,4,7 / 1$, $3,5 / 1$, que significa uma ultrapassagem do limite da apreensão do espaço pelo pedestre, onde já começa a ter uma dificuldade de percepção do todo configurado.

Quando a praça da Sé não era separada da praça Clóvis Bevilacqua (décadas de $30,40,50,60$ e início de 70 ), havia na Sé a relação $\mathrm{D} / \mathrm{H}=1 / 1$ e $1,6 / 1$, ou seja, o espaço em frente à catedral, a antiga praça da Sé, proporcionava uma clara definição de seu espaço livre. Os edifícios que circundaram a praça eram contínuos de forma a assumirem papel de verdadeiras paredes de um ambiente. 


\section{VALE DO ANHANGABAÚ}

O vale do Anhangabaú apresenta-se como um espaço todo especial, pois mesmo pela grande distância entre as edificações existe a sensação de domínio espacial onde os altos edifícios proporcionam a relação $\mathrm{D} / \mathrm{H}$ próxima a de $1 / 1$.

Na maior dimensão do vale, a relação D/H está em torno de 20/1. Esse número não revela um cercamento do espaço, entretanto, por estas construçōes como os viadutos do Chá e Santa Efigênia serem elementos referenciais do centro de São Paulo, eles acabam demarcando os dois extremos do espaço. Há um balizamento pelo aspecto simbólico.

Na menor dimensão as relações variam em tomo de $1 / 2$ a $2,2 / 1$, que revelam um equilíbrio entre espaço livre e edifícios.

Quando da época do palacete de Prates, a relação D/H girava em torno de 4,5/1 demostrando uma abertura do espaço e pouca definição.

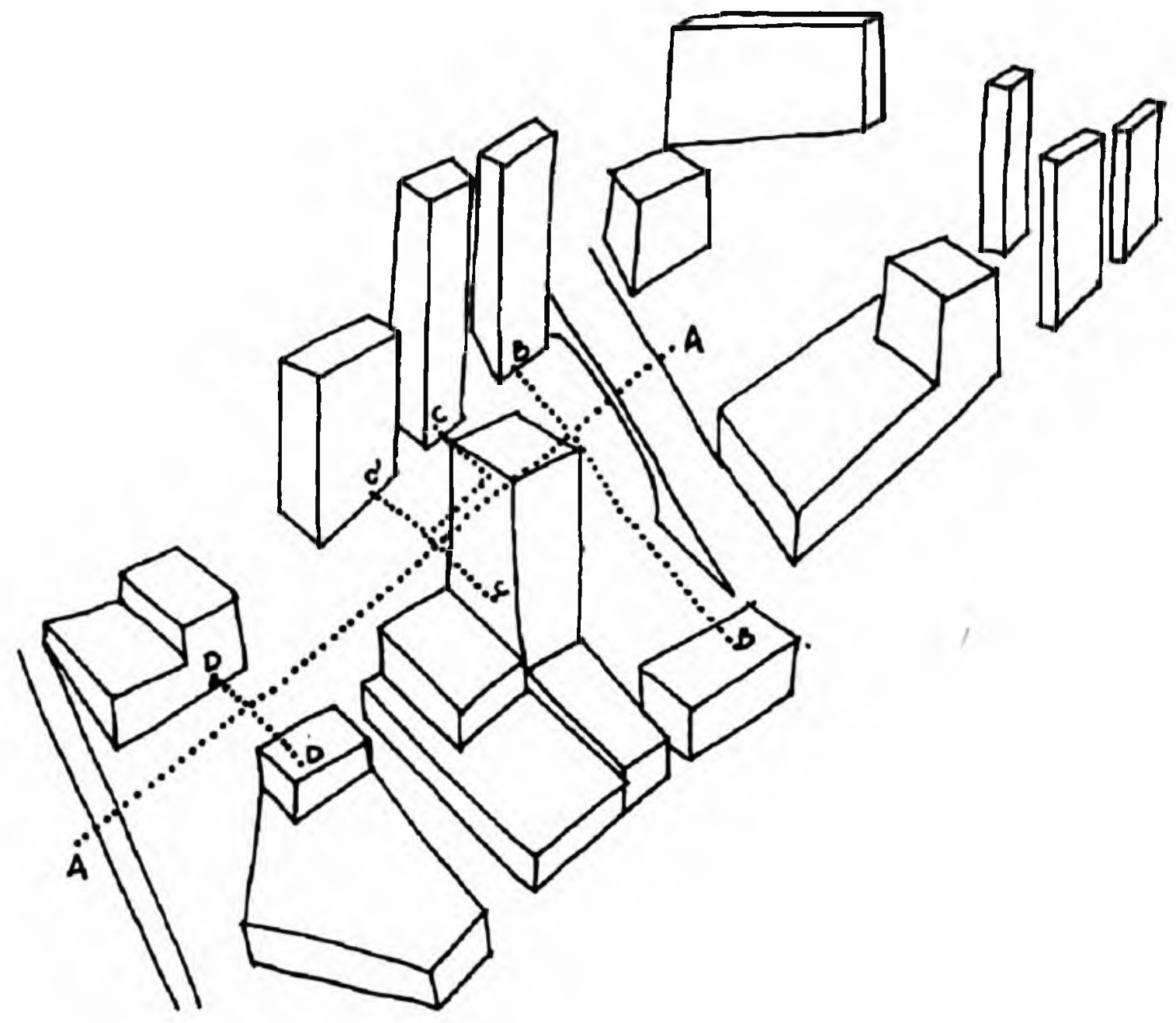



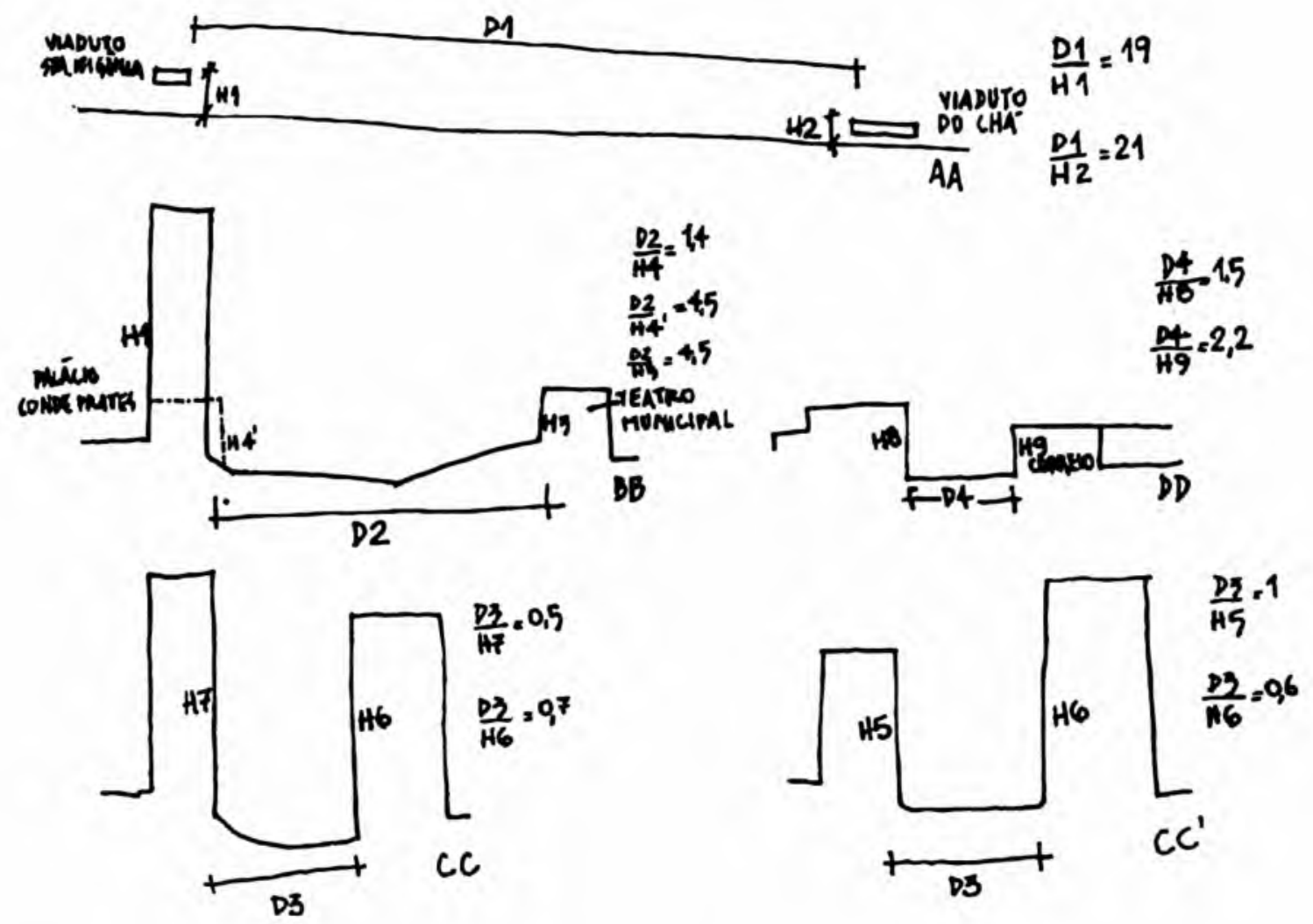

MEMORIAL DA AMÉRICA LATINA
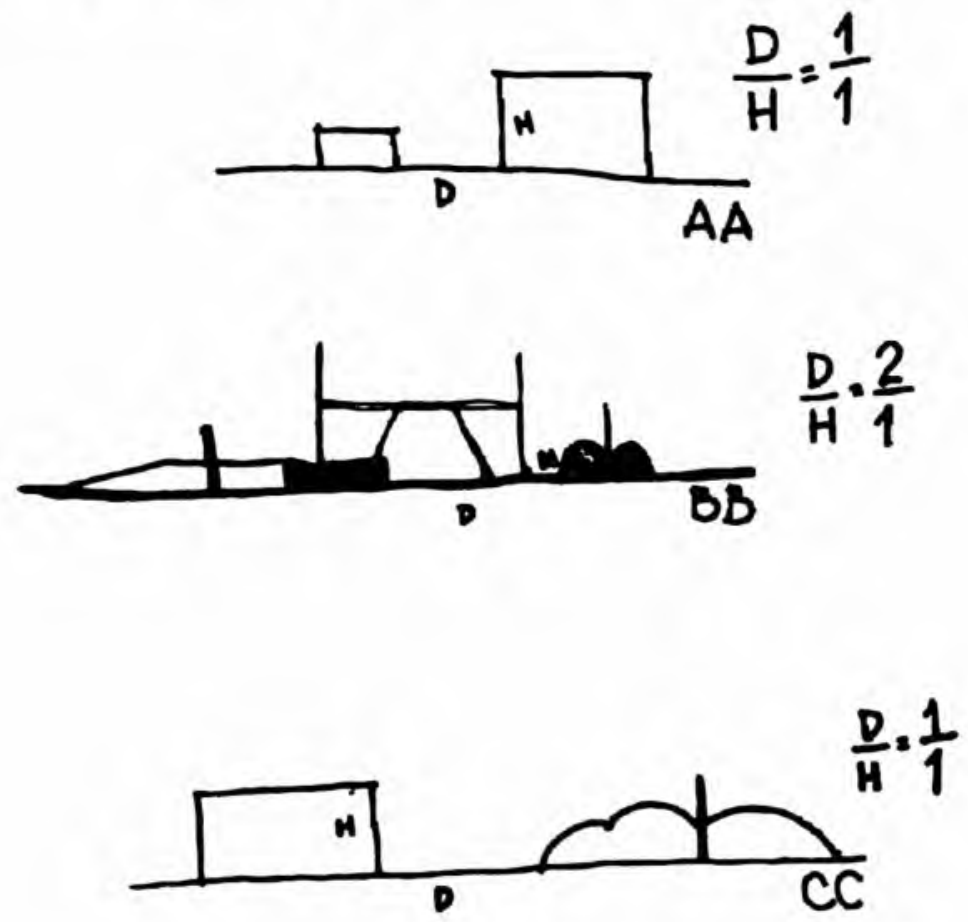
Internamente a relação $\mathrm{D} / \mathrm{H}$ existe em poucos pontos, como no espaço entre a Biblioteca e Restaurante, entre o Pavilhão da Criatividade e o Parlamento Latino Americano e entre o Parlamento e o Auditório que se aproximam de $\mathrm{D} / \mathrm{H}=1 / 1$. Os outros espaços entre os edifícios não têm definição espacial, fazendo com que o usuário ou visitante se sinta desorientado dentro desse projeto.

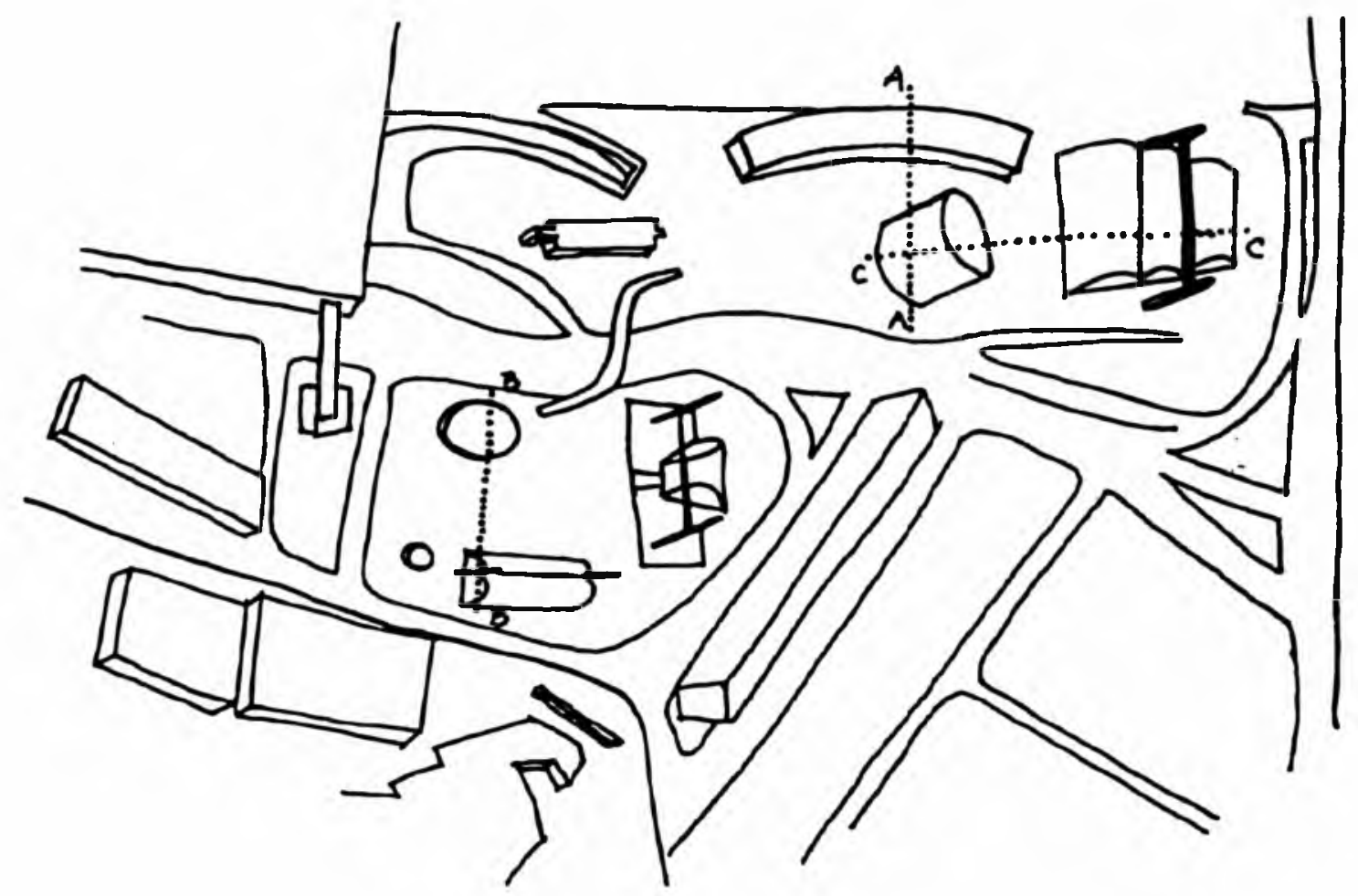

\section{CONCLUSĀO}

O desenvolvimento desse estudo contribui de forma positiva na conceituação de projetos de espaços livres públicos com caráter cívico.

Analisando os três espaços com tal caráter, praça da Sé, vale do Anhangabaú e Memorial da América Latina, podemos tomar num primeiro momento as diferentes estruturas espaciais.

Essas estruturas são resultantes de condiçðes particulares de cada espaço, tais como de função, aspectos históricos, de topografia, etc., e que incitam um determinado desenho para cada tipo de projeto.

Numa disposição paralela de análise desses três espaços, é possível discorrer simultaneamente a evolução histórica de cada um e se ter uma visão geral dos acontecimentos que condicionam a configuração de cada projeto. 
Nesta etapa, pode-se constatar que há uma dinâmica de transformação dos espaços que variam de acordo com a riqueza econômica da cidade, população, evolução da tecnologia disponível (transporte, comunicação, construção civil), filosofias políticas de governo, da utilização da população.

Partindo para a análise de elementos de projeto propriamente ditos, podemos avaliar as várias soluções adotadas para áreas de estar, acesso, circulação, pisos, sinalização, vegetação, etc. As diferentes soluções implantadas podem ser criticadas em suas falhas e os pontos positivos devem ser considerados no aumento de repertório de soluções projetuais.

A comparação também é utilizada na análise das relações de altura das construções (edifícios) e da distância entre estes, fundamental para a definição dos espaços livres de edificação; a proporção entre essas duas variáveis, juntamente com a noção de fechamento de espaços, são prementes na concepção de qualquer projeto, pois desta relação depende a sensação de espaço que queira se dar.

O método utilizado nesse trabalho tem embutido em si, um câmbio entre várias escalas, que permite, numa variação do mais geral para o mais particular, ter uma visão geral do espaço ao se propor um projeto. E a melhor compreensão de cada espaço, de sua essência, ficando dessa forma, com menos possibilidade de cometer erros conceituais e de soluções de projeto.

Em se tratando do resultado final da idéia de espaço público de caráter cívico, válido também para qualquer outro espaço, deve-se haver uma procura contínua de uma linguagem formal, que possibilite um discernimento no encontro do desenho de cada elemento e da estrutura geral, de maneira a proporcionar uma unidade formal.

Uma clareza na intenção de projeto e a decorrente apreensão do espaço pelo usuário, possuem influência de tal unidade formal acima descrita.

O propósito do caráter cívico de um espaço surge pela própria vontade da população de uma cidade, demostrada pela utilização, manifestações públicas, etc. $O$ projeto para tais espaços vem reforçar tal desejo, com o objetivo de adequação funcional, plástica e de conforto, bem como o de definição simbólica que aquele espaço vai identificar cidadão e cidade.

Os critérios de projeto podem ser melhor adotados após a compreensão de toda essa metodologia de análise e avaliação até aqui apresentada.

A composição plástica associada a considerações de conforto devem ter como premissa o melhor atendimento ao cidadão, ao usuário, que é toda a essência e propósito da cidade. 


\section{NOTAS}

(1) MAGNOLI, Miranda Maria Esmeralda. Espaços livres e urbanizaçāo: uma introdução à aspectos da paisagem metropolitana. São Paulo: FAUUSP, 1972.

(2) TOLEDO, Benedito Lima de. Sāo Paulo: três cidades em um século. São Paulo: Duas Cidades Ltda. 1983.

(3) ASHIHARA, Yoshinobu. El diseño de espacios exteriores. Barcelona: Gustavo Gili S/A, 1992.

(4) GREATER LONDON COUNCIL. An introduction to housing a layout. Londres: Architectural Press, 1978.

(5) SOARES, Dulce. Barra Funda: esquinas, fachadas e interiores. São Paulo: Imprensa Oficial do Estado, 1982.

\section{BIBLIOGRAFIA}

A PRAÇA pública na cidade invisível. $A U$. n. 34, p. 89, fev./mar. 1991.

ANHANGABAÚ Reurbanização devolve o vale ao povo. Projeto. n. 149, p. 100-103, jan./fev. 1992.

ANHANGABAU, uma conquista dos arquitetos e da população. Projeto. n. 31, p. 33-54, jul. 1981.

O NOVO ANHANGABAÚ: mais um passo para revitalização do centro. A Construçāo Sāo Paulo. n. 1.741, p. 4-11, 22-6-1981.

PRAÇA da Sé 1976. A Construçāo Sāo Paulo. n. 1.855, p. 23, 23-08-1983.

PROJETO do Vale do Anhangabaú. Projeto. n. 138, p. 51-53, 58-63, fev. 1991.

REORGANIZAÇĀO DO Vale do Anhangabaú. Projeto. n. 42, p. 153, jul. 1982.

A PRODUÇÃO cultural. Módulo. n. 100, p. 50-1, mar. 1989.

ASHIHARA, Yoshinobu. El diseño de espacios exteriores. Barcelona: Gustavo Gili S/A, 1992.

BARROS, Luiz Antônio Pecamar. A Memória volatiza-se no Memorial e a história afunda na barra. Projeto. n. 126, p. 12-3, out. 1989.

BATIMANCHI, Susana. Engenharia, Metamorfose completa/ Memorial da América Latina. A Construçāo Sāo Paulo. n. 2.149, p. 26-8, 17-4-1989.

BENEVOLO, Leonardo. O último capítulo da arquitetura Moderna. São Paulo: Martins Fontes, 1985.

BERTALINI, Vladimir. Praças do Metrô: enredo, produçāo, cenário, atores. São Paulo, 1988. vii, 169 p. ilus. plantas dobradas $30 \mathrm{~cm}$.

CONTINENTE sob os pés. $A U$. n. 23, p. 34, abr./maio 1989. 
CUJUMIJUAN, Pedro. Os prédios, a integração. Obra: Planejamento e Construção. n. 9, p. 18-23, nov. 1983.

CULLEN, Gordon. Towscape. Londres: Arquitetural Press, 1961.

DANTIN, Éden. O vão da América. A Construçāo São Paulo. n. 2.120, p. 16-21; p. 269, 26-09-1988.

DEL RIO, Vicente. Introduçāo ao desenho urbano de processo de planejamento. São Paulo: Pini, 1990.

ECKBO, Garrett. The landscape we see. Maindenhead: McGraw Hill Book Company, 1969. . Urban landscape design. Maindenhead: McGraw Hill Book Company, 1964.

FARRET, GONZALES, HOLANDA E KOHLSDORF. $O$ espaço da cidade.

FERRARA, Lucrécia D'Alessio. A estratégia dos signos.

GIEDION, S. Cities. Nova York: Reinhold, 1963. . Espacio, tiempo y arquitectura. B arcelona: Científico Médica, 1958. 2a. ed.

GLUSBERG, Jorge. Um símbolo da região. $A U$. n. 24, p. 52-4, jun./jul. 1989.

GREATER LONDON COUNCIL. An introduction to housing a layout. Londres: Architectural Press, 1978.

GUEDES SOBRINHO, Joaquim Manoel. 1989, Oscar Niemeyer na Barra Funda, em São Paulo. Revista USP. n. 5, p. 47-54, mar./maio 1990.

JACOBS, JANE. Muerte y Vida de las Grandes Ciudades Americanas.

KASIGUSSU, Cristina Vieira; CALDAS, Sérgio Túlio. Cultura: Acidentes de Percurso. A Construçāo Sāo Paulo. n. 2.149, p. 30-1, 17-4-1989.

KLIASS, Rosa Grena; KFOURI, Jamil José. Diversidade de formas. AU. n. 42, p. 32-34, jun./jul. 1992.

LAURIE, Michael. An introduction to landscape architecture. Londres: Pitman Publishing Limited, 1978.

LIPAI, Alexandre Emílio. Arquitetura: interaçōes homem/ambiente um estudo interdisciplinar. São Paulo: FAU, 1981.

LYNCH, Kavin. La imagem de la ciudad. Barcelona: Gustavo Gili S/A, 1980.

LYONNET, Jean Marc; EMERY, Marc. Rara Emoção. $A U$. n. 24, p. 48-9, jun./jul. 1989.

MACEDO, Silvio S. Higienópolis e arredores. São Paulo: Pini, 1987. . Paisagem. São Paulo: FAUUSP, Apostila, 1978. 
MAGALHÃES, Fábio. Passos: Memorial I. Design \& Interiores. n. 14, p. 20-4, jun. 1989.

MAGNOLI, Miranda M. Espaços livres e urbanizaçāo: Uma introduçāo a aspectos da paisagem metropolitana. São Paulo: FAUUSP, 1982.

MARX, Murilo. Cidade Brasileira. São Paulo: Edusp/Melhoramentos, 1980.

MORAES, Femando. A Integração Latino-americana. Módulo. n. 100, p. 44-7, mar. 1989.

MOURA, Éride. Operação Complexa. AU. n. 42, p. 32-34, jun./jul. 1992.

NIEMEYER, Oscar. Ato de fé e solidariedade. Projeto. n. 120, p. 67, abr. 1989.

Ato de Solidariedade Continental. Obra: planejamento e construçāo. n. 9, p. 18-23, nov. 1988.

Beleza é fundamental. A Construçăo Sāo Paulo. n. 1.142, p. 14-6, 27-2-89.

. De Pampulha ao Memorial da América Latina. Módulo. n. 100, p. 14-15, mar. 1989.

. Memorial da América Latina. Módulo. n. 100. p. 26-43, mar. 1989.

. Memorial da América Latina. Projeto. n. 120, p. 68-89, abr. 1989.

. Memorial da América Latina. Módulo. n. 97, p. 62-7, fev. 1989. Número especial.

. Visto por dentro. A Construçāo Sāo Paulo. n. 2.149, p. 25, 17-04-1989.

NISHIKAWA, Ayako. Espaços livres junto às habitaçōes em Sāo Paulo. São Paulo: FAUUSP, 1984.

NOBRE, Ana Luiza. Vale do Anhangabaú, São Paulo Nova feição do Centro. $A U$. n. 42, p. 32-34, jun./jul. 1992.

OLIVEIRA, Nildo Carlos. A estrutura é a própria concepção arquitetônica. Projeto. n. 120 , p. 86-7, abr. 1989.

PROJETO, São Paulo, 1985.

RIBEIRO, Darcy. O Memorial oscário. Módulo. n. 100, p. 110-3, mar. 1989.

RUGGEMBERG, Eduardo Subirats. Arquitetura e Poesia: dois exemplos latinoamericanos. Projeto. n. 193, p. 79.

SABBAG, Haifa Y. Arquitetura que não cria beleza não é arquitetura. A Construçāo Sāo Paulo. n. 2.149, p. 22-4, 17-4-89.

SANTOS, Carlos N. Quando a Rua vira Casa. 
SANTOS, Cecilia Rodrigues dos, SEGAWA, Hugo, ZEIN, Ruth Verde. Sonho poético na era dos computadores (entrevista com Karel Vollers). In: Projeto. n. 120, p. 76-7, abr./1989.

SANTOS, Luiz Carlos. Um marco cultural em São Paulo. In: Módulo. n. 100, p. 48-9, mar./1989.

SANTOS, Milton. Espaço e sociedade. Petrópolis: Vozes Ltda, 1972.

SITTE, Camilo. Camilo Sitte y el nascimiento del urbanismo moderno. Barcelona: Gustavo Gili, 1980.

. Construcción de ciudades segun principios artísticos. In: Collins, G. \& Collins, C.

STROETER, João Rodolfo. Oscar e o Memorial. Projeto. n. 120, p. 44-5, abr./1989.

SUSSEKIND, José Carlos. Desafio é cantoria... In: AU. n. 24, p. 50-1, jun./jul. 1989.

TAPERMAN, Sérgio. O Memorial da Memória. In: $A U$. n. 24, p. 55, jun./jul. 1989.

TENUE configuração na busca do sublime. $A U$. n. 24, p. 40-1, jun./jul. 1989.

WILHEIM, Jorge. De espaço a lugar. AU. n. 42, p. 32-34, jun./jul. 1992.

WOLF, Jose. (entrevista com Darcy Ribeiro).

XAVIER, Alberto Fernando Menchiades; LEMOS, Carlos Alberto Cerqueira; CORONA, Eduardo. Arquitetura moderna paulistana. São Paulo: Pini, 1983.

YI-FU, Tuan. Espaço e lugar: a perspectiva da experiência. São Paulo: Difel, 1983.

Topofilia: um estudo da percep̧̧ão, atitude e valores do meio ambiente. São Paulo: Difel, 1980.

ZEIN, Ruth Verde. Descubra os sete erros. In: Projeto. n. 120, p. 72-3, abr. 1989.

\section{REFERENCIAS DOS MAPAS}

Planta da cidade de São Paulo - 1881 - (detalhe). Levantada pela Companhia Cantareira de Esgotos Henry B. Joyner, m. 1. c. e. (mapa publicado pela Editora Melhoramentos em comemoração ao VI Centenário da cidade de São Paulo 1954).

Planta geral da capital de São Paulo - (Retificada) esc.: 1:20.000, 1897.

Prefeitura Municipal de São Paulo, Prefeito Sr. Dr. José Pires do Rio.

Mapa topográphico do Município de São Paulo. esc: 1:5.000, 1930 Município de São Paulo S. P., Prefeitura do Município.

Levantamento aerofotogramétrico do Município de São Paulo. São Paulo, PMSP, 1954. 
Município de São Paulo EMURB - Empresa Municipal de Urbanização.

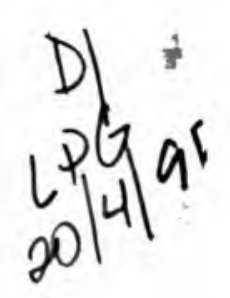

Sistema de Circulação.

Reconstrução da praça da Sé, esc.: 1:500, 1976.

(Desenho referência METRÔ Companhia Metropolitana de São Paulo. Promon Desenhos. n. ME 07 A STI 631; 036 C/908) Governo do Estado de São Paulo Secretaria dos Negócios Metropolitanos EMPLASA Empresa Metropolitana de Planejamento da Grande São Paulo S.A. Sistema Cartográfico Metropolitano.

Levantamento aerofutograméu Isc.: 1:10.000, 1981.

Companhia Metropolitana de São Paulo GPC. GPAR.

Implantação Geral Terminal Barra Funda Linha Leste-Oeste esc.: 1.2.000 de 3.06.04.00/1B2 - 001 folha 0 Município de São Paulo EMURB - Empresa Munıcipal de Urbanização.

Operação Anhangabaú.

Perímetro da Operação Anhangabaú, esc.: 1:2.000, junho de 1990 (desenho base 1973 GEGRAN) instituições responsáveis pela administração ou guarda do material dos projetos dos espaços citados:

a) Biblioteca e Departamento de Projetos de Arquitetura do Metrô;

b) Administração do Memorial da América Latina;

c) EMURB (Empresa Municipal de Urbanização);

d) Biblioteca da Faculdade de Arquitetura e Urbanismo da Universidade de São Paulo.

Além dessas instituições foi feita uma entrevista com os arquitetos do escritório de Arquitetura e Paisagismo: Koiti Mori e Klara Kaizer Mori Arquitetos Associados, responsáveis pelo projeto de paisagismo do Memorial da América Latina.

Entrevista com o arquiteto Jamil José Kfouri, do Grupo de arquitetos que venceu o concurso para o Vale do Anhangabaú. 